\title{
HSPH1 wt Allele
}

National Cancer Institute

\section{Source}

National Cancer Institute. HSPH1 wt Allele. NCI Thesaurus. Code C116975.

Human HSPH1 wild-type allele is located in the vicinity of $13 q 12.3$ and is approximately $26 \mathrm{~kb}$ in length. This allele, which encodes heat shock protein $105 \mathrm{kDa}$ protein, is involved in the negative regulation of the aggregation of unfolded proteins. 